\title{
New record of Boa constrictor occidentalis Philippi, 1873 (Serpentes: Boidae) in San Juan province, Argentina
}

\author{
Tomás A. Martínez*, Melina J. Rodriguez Muñoz, Ana P. Galdeano and Juan Carlos Acosta \\ Universidad Nacional de San Juan, Facultad de Ciencias Exactas, Físicas y Naturales, Departamento de Biología, Av. Ignacio de la Roza \\ 590 (O), CPA: J5402DCS, Rivadavia, San Juan, Argentina \\ * Corresponding author. E-mail: tomas.agustin.martinez14@gmail.com
}

\begin{abstract}
We document the first record of Boa constrictor in Valle Fértil department, San Juan province, Argentina. The specimen was collected and deposited in the herpetological collection of the Department of Biology, Universidad Nacional San Juan. This record extends the known distribution for this species in San Juan province by $105 \mathrm{~km}$.
\end{abstract}

Keywords: Boa constrictor, Argentina, San Juan province, Chaco Occidental, distribution

\section{INTRODUCTION}

The genus Boa is represented only by one species, Boa constrictor (Vences et al. 2001). This is one of the largest and most widely distributed snakes in America, showing great plasticity in the occupation of different ecosystems. Its distribution extends from northern Mexico to central Argentina, except Chile and Uruguay. It inhabits rainforests, savannas, forests and semidesert scrub of most tropical and subtropical areas of the continent. Because of its wide distribution, morphological variability and the lack of taxonomic and systematic studies (Scrocchi, pers. comm.), several subspecies have been named (Langhammer 1983; Peters and Orejas-Miranda 1986; Price and Russo 1991). Boa constrictor occidentalis is the southernmost subspecies (Bertona and Charaviglio 2003).

Boa constrictor occidentalis is associated with burrows of vizcachas (Lagostomus maximus), for both prey and refuge (Cei 1993; Sironi et al. 2000). Males and females reach sexual maturity at an average snout-vent length (SVL) of $149 \mathrm{~cm}$ and $164 \mathrm{~cm}$, respectively (Chiaraviglio et al. 2001). The species is subject to strong human pressures for skins and the pet trade (Ávila and Acosta 1996), and its habitat is being severely modified by intense farming and cattle raising in Argentina. As a consequence, it is considered a threatened species (Giraudo et al. 2012; Acosta et al. in press) and has been included in Appendix I of CITES (2014).

The systematic listing of Argentine snakes (Giraudo and Scrocchi 2002) shows B. c. occidentalis occurring in 13 provinces: Chaco, Formosa, Salta, Jujuy, Tucumán, Santiago del Estero, Santa Fe, La Rioja, Catamarca, Córdoba, San Juan, San Luis and Mendoza. It is distributed mainly in the ecoregions of Chaco Oriental, Occidental and Serrano, and the northwest of Espinal (Di Fonzo de Ábalos and Bucher 1981; Reati 1996; Chiaraviglio et al. 1998). In San Juan province, existing data are scarce and mostly anecdotal. In this note we confirm the presence of B. c. occidentalis in Valle Fértil department of San Juan province, constituting the first record with voucher for this department. Precise information on its distribution is also provided.

On 28 December 2014 at 23:56 $\mathrm{h}$ we found a road-killed juvenile B. c. occidentalis, SVL $137.7 \mathrm{~cm}$, on Provincial Route $510,20 \mathrm{~km}$ south of San Agustín de Valle Fértil ( $30^{\circ} 48^{\prime} 03^{\prime \prime} \mathrm{S}, 067^{\circ} 22^{\prime} \mathrm{O} 4^{\prime \prime} \mathrm{W}, 762 \mathrm{~m}$ above sea level) (Figure 1). The specimen was collected and deposited in the scientific herpetological collection of the Department of Biology, Facultad Ciencias Exactas, Físicas y Naturales, Universidad Nacional San Juan (UNSJ-2098).

The individual was identified as B. c. occidentalis by morphological comparisons with reference material in the herpetological collection of UNSJ, and verified by Juan Carlos Acosta.

In Argentina, the distribution of B. c. occidentalis has not been studied in detail. However, there are several studies that have contributed information about its range. Boa constrictor occidentalis has been reported in provinces of Chaco (Kacoliris 2006; Alvarez et al. 2009), Formosa (Lions et al. 1997; Alvarez et al. 2009), Santa Fé (Arzamendia and Giraudo 2002; Bosisio and Trucco 2002), Córdoba (Di Fonzo de Ábalos and Bucher 1981; Chiaraviglio et al. 1998; Briguera et al. 2005; Pelegrin et al. 2006), San Luis (Jackson 1986, Ávila and Carrizo 2003; Guerreiro et al. 2005), Salta (Cruz et al. 1992; Lavilla et al. 1995), Mendoza (Cei and Roig 1973), 


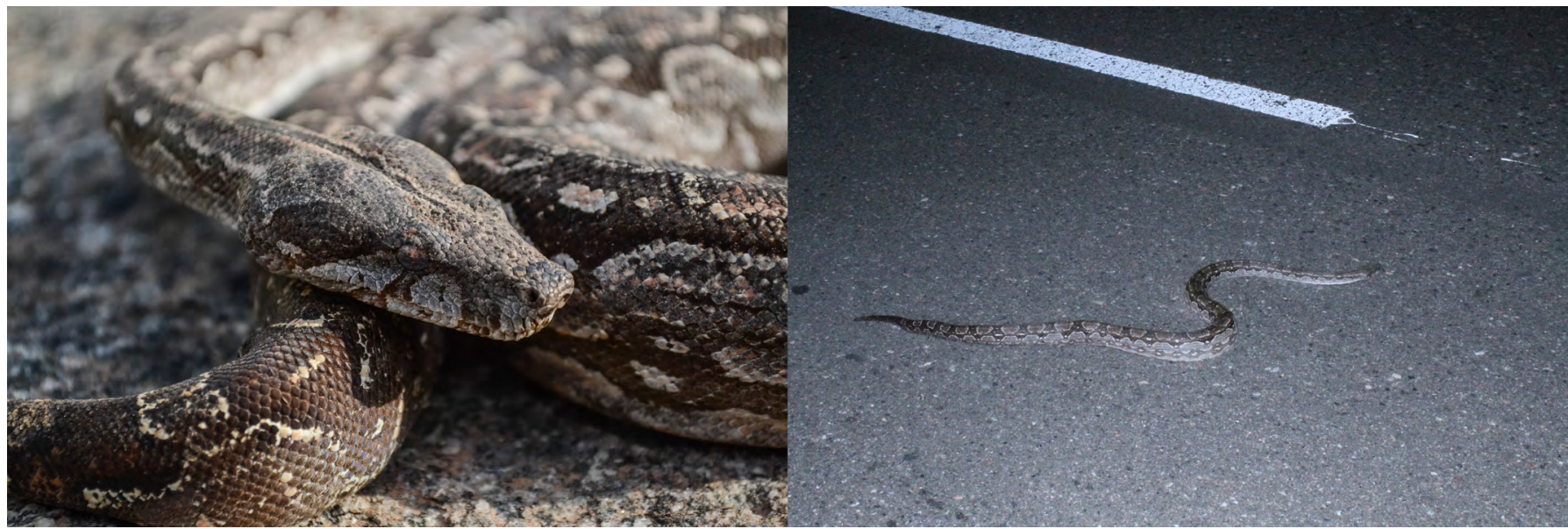

Figure 1. Boa constrictor occidentalis UNSJ 2098 on Provincial Route 510 in Valle Fértil department, San Juan province, Argentina.

Tucumán (Laurent and Terán 1981), and San Juan (Ávila et al. 1998; Acosta and Ávila 2001; Laspiur et al. 2010). Giraudo and Scrocchi (2002) also included it in La Rioja, Santiago del Estero, Jujuy, and Catamarca. Recent studies have attempted to represent its distribution in Argentina based on observational records according to several environmental factors (Di Cola et al. 2008), and through surveys (Waller et al. 2010) (Figure 2).

According to Ávila et al. (1998), Boa constrictor occidentalis occurs in east-central San Juan province. Cei and Castro (1978), report it from Sierra Guayaguas and Pampa del Gigantillo, 25 de Mayo department, and also Valle Fértil department, but without voucher material. The presence of $B$. constrictor occidentalis in the province was confirmed, with reference material, in Caucete department, in the southeastern part of the province (Acosta and Avila 2001). Laspiur et al. (2010) observed an adult in the Sierra de Guayaguas, 25 de Mayo department, the most recent record for the province.

The site reported in this note is in the Chaco Occidental ecoregion, which is consistent with previous reports (Di Fonzo de Ábalos and Bucher 1981; Reati 1996; Chiaraviglio et al. 1998; Acosta et al. 200o; Laspiur et al. 2010). Our record extends the distribution in San Juan $105 \mathrm{~km}$ north, in the eastern part of the province. It also extends its distribution area in Argentina $121 \mathrm{~km}$ farther west from the range predicted by Di Cola et al. (2008) and $8 \mathrm{~km}$ west of that predicted by Waller et al. (2010) (Figure 2).

Specimens of B.c. occidentalis are rare in herpetological collections, making it difficult to determine its precise distribution (Acosta and Ávila 2001). Previous records of the subspecies in Valle Fértil are anecdotal (Cei and Castro 1978). Here we confirm for the first time for

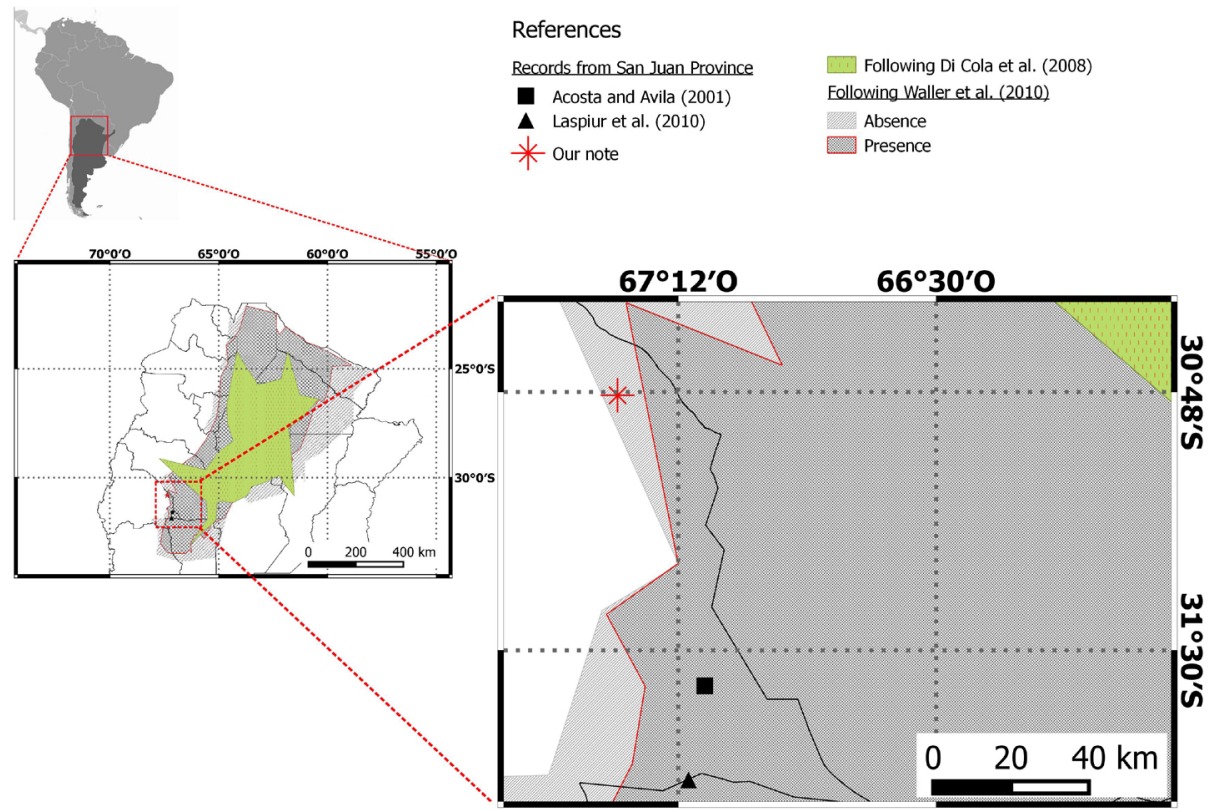

Figure 2. Distribution of Boa constrictor occidentalis in Argentina. Green Area: Distribution area according to Di Cola et al. (2008). Grey Area: Distribution area according to Waller et al. (2010). Light Grey: Absence area according to Waller et al. (2010). Square: individual registered in Caucete department by Acosta and Ávila (2001). Triangle: individual registered by Laspiur et al. (2010) in 25 de Mayo department. Star: New record that confirms the presence of the subspecies in Valle Fértil department. 
this department the presence of B. c. occidentalis with reference material in scientific collection and extends its known distribution in Argentina.

\section{ACKNOWLEDGEMENTS}

We thank Gustavo Fava for his help in making the map. We also thank Nicolás Sisterna for his assistance in translating earlier versions of this manuscript.

\section{LITERATURE CITED}

Acosta, J.C. and L.J. Ávila. 2001. Distribución geográfica de Boa constrictor occidentalis. Linnaeus, 1758 (Serpentes: Boidae) Cuadernos de Herpetología 14(2): 163.

Acosta, J.C., A. Laspiur, G. Blanco and H.J. Villavicencio. In press. Diversidad y Conservación de Anfibios y reptiles de San Juan; in press, in: E. Martínez Carretero and A. García (eds.). San Juan Ambiental. San Juan: Universidad Nacional de San Juan.

Alvarez, B.B., J.A. Ruiz García, J.A. Céspedez, A.B. Hernando, V.H. Zaracho, C.C. Calamante and R.H. Aguirre. 2009. Herpetofauna, provinces of Chaco and Formosa, Chaco Oriental region, northeastern Argentina. Check List 5(1): 74-82.

Arzamendia, V. and A.R. Giraudo. 2002. Lista y distribución de los ofidios (Reptilia: Serpentes) de Santa Fe, Argentina. Cuadernos de Herpetología 16(1): 15-32. http://hdl.handle.net/10915/6363

Ávila, L.J. and J.C. Acosta. 1996. Evaluación del estado de conservación de la fauna de saurios anfisbénidos y anfibios de la provincia de Córdoba (Argentina). Facena 12: 77-92.

Ávila, L.J., J.C. Acosta and F. Murúa. 1998. Herpetofauna de la provincia de San Juan, Argentina: lista comentada y distribución geográfica. Cuadernos de Herpetología 12(1): 11-29.

Ávila, L.J. and G.R. Carrizo. 2003. Lista comentada y distribución geográfica de la herpetofauna de la provincia de San Luis, Argentina. Acta Zoológica Lilloana 47(1-2): 93-115.

Bertona, M. and M. Chiaraviglio. 2003. Reproductive biology, mating aggregations, and sexual dimorphism of the Argentine Boa Constrictor (Boa constrictor occidentalis). Journal of Herpetology 37(3): 510-516. doi: 10.1670/122-02A

Bosisio, A.C. and M.F. Trucco. 2002. Listado sistemático de los ofidios pertenecientes a la colección herpetológica del Museo Provincial de Ciencias Naturales "Florentino Ameghino", Santa Fe, Argentina. Museo Provincial de Ciencias Naturales "Florentino Ameghino", Serie Catálogos 6: 1-16.

Briguera, V., D. Tamburini, M. Kufner, G. Gavier, L. Giraudo, R. Torres and V. Bechara. 2005. Herpetofauna en relictos de bosque chaqueño de la region de Mar Chiquita, Córdoba. Cuadernos de Herpetología 20(1): 25-31.

Cei, J.M. 1993. Reptiles del noroeste, nordeste y este de la Argentina. Herpetofauna de las selvas subtropicales, Puna y Pampas. Monografía XIV, Torino: Museo Regionale di Scienze Naturali. 949 pp.

Cei, J.M. and L.P. Castro. 1978. Datos preliminares sobre las componentes de la herpetofauna de la provincia de San Juan. Publicaciones Ocasionales del Instituto de Biología Animal. Facultad de Ciencias Agrarias Universidad Nacional de Cuyo. Serie Científica. 5 pp.

Cei, J.M. and V.G. Roig. 1973. Fauna y ecosistemas del oeste árido argentino. I. Reptiles de la provincia de Mendoza. Deserta 1973(4): 69-90.

Chiaraviglio, M. and V. Briguera. 2001. Participación de señales químicas en el reconocimiento y discriminación de sexos en Boa constrictor occidentalis (Serpentes, Boidae). Gayana 65(1): 5-10. doi: 10.4067/So717-65382001000100002

Chiaraviglio, M., M. Bertona, M. Sironi and R. Cervantes. 1998. Distribución de Boa constrictor occidentalis (Serpentes: Boidae) en el noroeste de la provincia de Córdoba, Argentina. Gayana Zoología 62(1): 75-77. doi: 10.1670/122-02A

CITES. 2015. Apéndices I, II y III, Version 2015. Convención sobre el Comercio Internacional de Especies Amenazadas de Fauna y Flora Silvestres. Accessed at: https://www.cites.org/sites/default/files/ esp/app/2015/S-Appendices-2015-02-15.pdf, 1 March 2015.

Cruz, F.B., M.G. Pierotti and L.A. Fitzgerald. 1992. Lista de anfibios y reptiles colectados en una localidad del chaco salteño. Acta Zoológica Lilloana 42(1): 101-107.

Di Cola, V., G. Cardozo, M. Lanfri, M. Scavuzzo and M. Chiaraviglio. 2008. Modelling the distribution of the Boid snakes, Epicrates cenchria alvarezi and Boa constrictor occidentalis in the Gran Chaco (South America). Amphibia-Reptilia 29: 299-310. doi: 10.1163/156853808785112138

Di Fonzo de Ábalos, A. and E.H. Bucher. 1981. La fauna de serpientes de la provincia de Córdoba, Argentina. I. Lista y distribución. Ecosur 8(16): 89-98.

Giraudo, A.R. and G.J. Scrocchi. 2002. Argentinean snakes: an annotated checklist. Washington, D.C.: Smithsonian Herpetological Information Service 132 (Smithsonian Institution). 53 pp. doi: 10.5479/si.23317515.132.1

Giraudo, A.R., V. Arzamendia, G.P. Bellini, C.A. Bessa, C.C. Calamante, G. Cardozo, M. Chiaraviglio, M.B. Costanzo, E.G. Etchepare, V. Di Cola, D.O. Di Pietro, S. Kretzschmar, S. Palomas, S.J. Nenda, P.C. Rivera, M.A. Rodríguez, G.J. Scrocchi and J.D. Williams. 2012. Categorización del estado de conservación de las Serpientes de la República Argentina. Cuadernos de Herpetología 26: 303-326.

Guerreiro, A., J.C. Baldoni and A.M. Brigada. 2005. Herpetofauna de Sierra de las Quijadas (San Luis, Argentina). Gayana (Concepción) 69(1): 6-9. doi: 10.4067/S0717-65382005000100002

Jackson, J.E. 1986. Atlas de algunos vertebrados silvestres de importancia socio-económico en la provincia de San Luis. San Luis: INTA Villa Mercedes. 24pp.

Kacoliris, F.P., I. Berkunsky and J. Williams. 2006. Herpetofauna of the Argentinean Impenetrable Great Chaco. Phyllomedusa 5(2): 149-157. doi: 10.11606/issn.2316-9079.v5i2p149-157

Langhammer, J.K. 1983. A new subspecies of Boa constrictor, Boa constrictor melanogaster, from Ecuador (Serpentes: Boidae). Tropical Fish Hobbyist 32(4): 70-79.

Laspiur, A., J.C. Acosta, J. Marquez and G. Blanco. 2010. Boa constrictor occidentalis (Argentine boa) Diet. Herpetological Review 41(3): 361-362.

Laurent, R.F. and E.M. Terán. 1981. Lista de los anfibios y reptiles de la provincia de Tucumán. Fundación Miguel Lillo, Miscelánea 71: 5-15.

Lavilla, E., F.B. Cruz and G.J. Scrocchi. 1995. Amphibiens et Reptiles de la Station Biologique "Los Colorados" dans la province de Salta, Argentine. Revue Francaise d'Aquariolgie-Herpétologie, 22: 51-58.

Lions, M.L., R.H. Aguirre, J.A. Cespedez and B.B. Alvarez. 1997. Reptiles de las áreas protegidas del oeste de la provincia de Formosa, Argentina. Facena 13: 43-48.

Pelegrin, N., G.C. Leynaud and E.H. Bucher. 2006. Reptile fauna of the Chancaní Reserve (Arid Chaco, Argentina): species list and conservation status. Herpetozoa 19: 85-86.

Peters, J.A. and B.R. Orejas-Miranda. 1986. Catalogue of Neotropical Squamata; Part I, Snakes. Washington, D.C.: Smithsonian Institution Press. 347 pp.

Price, R.M. and P. Russo. 1991. Revisionary comments on the genus Boa with the description of a new subspecies of Boa constrictor from Peru. The Snake 23: 29-35.

Reati, G.J. 1996. Serpientes de la provincia de Córdoba; pp. 239-254, in: I.E. Di Tada and E.H. Bucher (eds.). Biodiversidad de la Provincia de Córdoba, Vol. 1. Córdoba: Universidad Nacional de Río Cuarto.

Rogel, T.G. 1998. Uso del hábitat por Boa constrictor occidentalis en 
el oeste de la provincia de Córdoba, Argentina; Tesis, pp. 44. Facultad de Ciencias Exactas, Físicas y Naturales. Córdoba: Universidad Nacional de Córdoba.

Scrocchi, G.J., J.C. Moreta and S. Kretzschmar. 2006. Serpientes del noroeste argentino. Fundación Miguel Lillo. Tucumán. 174 pp.

Sironi, M., M. Chiaraviglio, R. Cervantes, M. Bertona, and M. Río. 200o. Dietary habits of Boa constrictor occidentalis, in the Córdoba Province, Argentina. Amphibia-Reptilia 21(2): 226-232.

Vences, M., F. Glaw, J. Kosuch, W. Böhme, and M. Veith. 2001. Phylogeny of South American and Malagasy Boine snakes: molecular evidence for the validity of Sanzinia and Acrantophis and biogeographic implications. Copeia 2001(4): 1151-1154. http://www.jstor.org/stable/1448408
Waller, T., P. Micucci, M. Barros, J. Draque and C. Estavillo. 2010. Conservación de la boa ampalagua (Boa constrictor occidentalis) en la República Argentina. Fundación Biodiversidad, Argentina. $77 \mathrm{pp}$.

Authors' contribution statement: MT, RMM and GA collected the specimen, AJC, MT, RMM and GA identified the species, MT, RMM and GA wrote the text, MT, RMM and GA designed the map, GA edited the images.

Received: 19 July 2015

Accepted: 16 September 2015

Editorial responsibility: $\mathrm{Ross} \mathrm{MacCulloch}$ 